LEGAL AND POLITICAL SCIENCE

\title{
SIGNIFICANT MEASURES OF STATE SUPPORT FOR BUSINESS (Comparative Analysis)
}

\author{
K. Kokrashvili, Doctor of Law, Professor of Georgian Technical University, Tbilisi, Georgia, \\ R. Kutateladze, Doctor of Economics and Technology, Professor of Georgian Technical University, \\ Dean of the Faculty of Business Technology at GTU, Tbilisi, Georgia, \\ N. Pailodze, Doctor of Technology, Professor of Georgian Technical University, Tbilisi, Georgia \\ DOI: https://doi.org/10.31435/rsglobal_conf/25012021/7364
}

\begin{abstract}
The paper describes the governmental activities for business support carried out by Georgia and foreign developed countries. The comparative analysis and the effectiveness of the results of the implemented measures have been presented and analyzed. The situation in Georgia has been highlighted and better opportunities of the support for small and medium-sized enterprises in our country have also been identified and presented in the given paper. State support for entrepreneurial activity is the deliberate creation of legal and economic conditions and incentives by the state for business development in the country. According to entrepreneurs, it is the state's responsibility to create all the conditions for business development in the country and also to assist the entrepreneurs in achieving their goals, such as maximizing profit, investment efficiency, risk minimization, entrepreneurial security, protection of property rights etc.
\end{abstract}

Keywords: State support; Business support; Small entrepreneurship; Anti-crisis measures; Association agreement.

Introduction. The constitution of the country is the essential and significant basis for the regulation of the economy by the state. The fundamental law of almost all countries, including the Constitution of Georgia, declares Georgia to be a social state (Article 5). The mentioned fact implies that "the state cares about the strengthening the principles of social justice, social equality and social solidarity in society. The state cares for the equal socio-economic and demographic development throughout the country. The law creates special conditions for the development of mountainous regions. The state cares about human health and social protection, about the provision of the subsistence minimum and decent housing, about the protection of family welfare. The state promotes employment of citizens. The conditions for providing the subsistence minimum are defined by the law. The state cares about environmental protection and rational use of natural resources." In one of its decisions in 2002, the Constitutional Court of Georgia ruled that the state should make every effort to ensure at least a minimum level of protection of social rights. The principle of a social state not only obliges the state, but also imposes solidarity obligations, creates social responsibility of individuals, so that their property can be used to some extent for the benefit of the society. In such a society property obliges, it has some social bound applying to everyone who owns the property. Sometimes, a democratic and legal state, for objective reasons, fails to provide even the minimum level of social security. In such cases, not only the results and success of the state's efforts are crucial - it's also crucial to see that "the state does its maximum to provide at least the minimum". ${ }^{1}$

Article 6 of the Constitution of Georgia recognizes economic freedom, in particular, the state cares about the development of free and open economy, free entrepreneurship and competition. It is inadmissible to abolish the universal right to the private property. Entrepreneurial activities of the state are subject not only to legal regulation, but also to the active implementation of supportive measures.

Research Results. The best state policy can be implemented at the intersection of the interests and goals of the state and the private sector. This is where the strategy and tactics of the state regulation of entrepreneurial activity come from. ${ }^{2}$

The state, as a major regulator, also has the function of supporting entrepreneurial activity. Worldwide practice demonstrates that multilateral support by the state is needed for the development

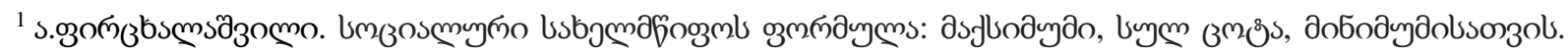
European.ge.2017.

${ }^{2}$ Государственное регулирование рыночной экономики. Под ред. Кушлина В.И. 2-е изд., перераб. и доп. - М.: РАГС, 2005. c.76
} 
of entrepreneurial relationships, which can be achieved through co-financing of certain areas or programs, establishing a favorable system, subsidizing and generally creating a favorable business environment for development.

State support for entrepreneurial activity is a series of activities, which implies creation of economic and legal conditions to stimulate entrepreneurship development, as well as its financial and material support. In the process, the interests of both the public and private sectors must be equally protected. This should become the basis of the state strategy for the development of economy.

It is not easy to realize the above mentioned activity. It is important for the state to apply the stimulating norms along with the prohibited ones.

Creating the system of the state support for entrepreneurial activity is a multistage and complex act, being a very complex and long-term process due to its content and prospect of real implementation. The mentioned process should be based on:

$>$ The relevant legislative framework;

$>$ The protection of the rights of the subjects implementing entrepreneurship;

$>$ The system of special institutions providing business support;

$>$ The support with financial resources.

In the countries with developed market economies, an effective, multilevel mechanism of cooperation between the state and entrepreneurship has long been established. In such countries creating favorable conditions for the development of small and medium-sized enterprises is seen as an important area of public policy. From the point of view of small business representatives, the state should create the necessary conditions under which small business can succeed. In line with the interests and goals of the state and SMEs, effective state policy can be pursued in this area. This defines the state's strategy and tactics regarding small business ${ }^{1}$.

No less important is the infrastructure support for small and medium-sized businesses, which has actively been pursued in foreign developed economies for the last 50 years. In Germany, for example, the development of technological infrastructure has received a great deal of state attention. Already in 1978 the German Federal Government approved the "General Concept of ScientificTechnical Policy for Small and Medium Businesses", defining forms and mechanisms of technical assistance for small businesses. In the 1980s technology parks, research institutes, and an appropriate transportation network were created for this purpose. To plan strategically the activities of higher education institutions and support small enterprises the Federal Chamber of Industry and Commerce established advisory centers and the commission for stimulating technological transfer. In 1989 the German government developed the concept of stimulating scientific research in small business, which provides information and consulting services in the field of new technologies, transformation of the vocational education, and training the personnel. As a result, German small and medium-sized enterprises are very successful in producing and promoting scientific innovations. The share of German businesses in financing research and design is $63 \%$, including $17 \%$ for SMEs. ${ }^{2}$

It would be beneficial for our state to share the German experience. In Georgia since 2016 the law on "innovations" has been functioning. The mentioned law "aims at creating and improving the national innovation eco-system necessary for socio-economic development of Georgia, at building the knowledge and innovation-based economy, at promoting in Georgia the use of technologies created in other countries, at supporting the introduction of the intellectual property and technologies creating in Georgia, at fostering export, at penetrating all areas of the advanced technologies, science and economy in order to increase the competitiveness of the mentioned area" (The first article).

This law creates an opportunity to bring education / science and production closer together and create a unified cycle. "Innovative activities are crucial in raising the technological level of production and competitiveness of products. It is aimed at utilizing the results of scientific research and processing to obtain new or missing goods or services, the manner in which they are manufactured, and for their effective sale on the domestic and foreign markets"3. The importance of innovation in the business of any country is great. It gives the enterprise a chance to break away from its competitors

\footnotetext{
${ }^{1}$ In 1985 the law on tax cuts, designed to reduce the tax burden on small businesses, was adopted in Germany. In 1990, the marginal rate of the income tax was reduced to $53 \%$ and the minimal rate- to $19 \%$. From January 1, 1990, small businesses were fully exempt from turnover tax not exceeding DEM 25,000 (before that limit was DEM 20,000).

2 Рубе В.А. Малый бизнес: история, теория, практика. - М.: ТЕИС, 2000.с. 72.

${ }^{3}$ http://www.nplg.gov.ge/gwdict/index.php?a=term \&d=5\&t=16350
} 
and take the leading position in the market in the shortest possible time. It is important for the country's economy - more innovation is directly proportional to the country's economic growth.

In Germany small businesses perform a number of functions, primarily promoting competition in the country's market. Small businesses are more customer-focused, making it easier to adapt to the customer needs and tastes. Such enterprises employ more than half of the German population and, ultimately, small businesses are an important segment of the German budget. Today Germany, the United States, Japan, Italy and the UK are ranked fifth in the world in terms of the number of small business enterprises. ${ }^{1}$

Under the German law, small entrepreneurs are given long-term (20-year) credits, with startup entrepreneurs not paying interest on the loan for two years after the company was founded, and the next 8 years on a grace basis. KFW Bank of Germany is actively involved in small business lending. The so-called "special credits" for those who start their own business (Existenzgründer) are especially important. The amount of the loan is $€ 100,000$, individuals (micro-businesses) are the recipients of the loan. The loans are given to small businesses with grace payment for the first 5 years. The German bank KFW is actively involved in lending them and, what is more important, takes on $80 \%$ of the risk (the remaining $20 \%$ is covered directly by the customer service bank).

As for our country, Chapter 12 of the Tax Code of Georgia deals with special taxation regimes that apply to: a) individuals with micro business status, b) entrepreneurs with small business status, c) persons with fixed taxpayer status (Code 83- Article e).

The status of a micro-business may be granted to a physical person who does not use the employment of hired persons and conducts economic activity independently of which the aggregate gross income received by him / her does not exceed GEL 30,000 per calendar year. The granting and revocation of the micro-business status, as well as the issue of the business certificate is performed in accordance with the procedure established by the Minister of Finance of Georgia (Article 84 (1) and (5) of the Code).

The implementation of a small business development policy is a key requirement of the EU towards partner countries. Thus, Georgia, as a country associated with the European Union, is required to comply strictly with European standards.

"The SME Development Strategy of Georgia for 2016-2020" has been created for the purpose of SME development in Georgia. ${ }^{2}$ It is noteworthy that in our country the project "Development of Small and Medium Entrepreneurship and DCFTA in Georgia" has been functioning from 2015 to 2019. The project was co-financed by the European Union and implemented by the German International Cooperation Society (GIZ). The project aims at supporting institutional and regulatory environment reforms related to the implementation of Deep and Comprehensive Free Trade Area (DCFTA). The project aims at strengthening the capacity of SMEs to increase the competitiveness of this sector and adapt it to the new regulatory environment. The purpose of the project is to prepare fertile soil for strengthening SMEs in Georgia and ensure large-scale economic growth.

International experience in the field of small business shows that small enterprises can function successfully if an effective economic policy to support small entrepreneurs is developed and implemented. The main requirement of the EU towards partner countries is the introduction of a small business development promotion policy. Georgia, as a country associated with the European Union, is required to adhere to European standards. Georgian politics has a clear European integration strategy, which is confirmed by the Association and Free Trade Agreements signed with the EU in June 2014. These agreements facilitate the process of integrating Georgian legislation with the EU model, which includes supporting the accelerated development of small businesses. Chapter 5 of Association Agreement is important in this regard, according to which, it is important to introduce a "Small Business Act", the principle of "think small first" emphasizes the importance of consulting with small entrepreneurs and taking into account their requirements. Special steps must be taken by the state to realize the issue at the political, administrative and institutional levels.

Today in the global pandemic the state support for business is especially important. Small businesses need special assistance from the state, accounting for an average of $60 \%$ of the private sector. The negative impact of the pandemic on small businesses is especially damaging. The number of active business owners worldwide has decreased dramatically. To mitigate the impact of these

\footnotetext{
1 Правовое регулирование и государственной поддержки малого предпринимательства в Германии. Гималетдинова К. А. Свинцицкая Е.В. 2019. с. 76-77.

${ }^{2}$ http://www.economy.ge/uploads/ecopolitic.
} 
changes, the economies of countries have gone through many crises, including revising procurement procedures, getting small firms, and increasing regulator discretion. According to the World Bank, countries in the recovery phase are supporting small businesses in a variety of ways.

Today, when the world is in a crisis caused by a global pandemic, business support is becoming increasingly important. In this sense extending short-term finance is the most widely used type of support. New lending under concessional terms, delayed repayments, restructuring and rescheduling, credit guarantees with new schemes, and capital buffer safeguards - such as lowering capital requirements on banks and central banks' actions to induce commercial banks to increase lending to business - are some examples of finance instruments used by various economies. For example, the French government has attempted to increase the liquidity of companies through state-guaranteed loans or investments in minority equity positions (EUR 3.5 billion). These schemes go beyond the assistance provided in the EUR 16 billion loan guarantee program announced during the early crisis response period in April 2020. Such measures are less feasible in low and lower middle-income countries, where governments have instead focused on reductions in the corporate income tax rate and expedited tax refunds. ${ }^{1}$

The coronavirus epidemic has provoked a surge of rulemaking activity. Parliament and the government are considering varied measures to eliminate the consequences of the epidemic. World practice shows that the most important business measures in the current situation are:

$>$ the government has a right to impose a moratorium on the initiation of insolvency proceedings;

$>$ there are restrictions on the conduct of inspections by regulatory authorities;

$>$ tenants have a right to deferred lease payments ("rent holidays") and to a decrease in payment for the period of quarantine;

$>$ borrowers have a right to request deferred payment of a loan ("credit holidays");

$>$ social insurance contributions for the salary fund have been halved for small and mediumsized businesses;

$>$ there has been a deferral of taxes and insurance contributions. ${ }^{2}$

The global crisis caused by the pandemic is unclassical. Today no one knows when it will end and what economic and financial damage it will bring to the world. While th governments of the countries are taking measures to support business, accirdung to economists, the global loss ar a result of the pandemic crisis will be around 9 trillion dollars (greater than the economies of Japan and Germany, combined.) For the first time since the Great Depression both advanced economies and emerging market and developing economies are in recession.

The crisis was transmitted primarily by trade and financial flows forcing millions back into poverty. Attainment of the Millennium Development Goals is seriously jeopardised in many countries. Many developing countries did not and do not have the resources to stimulate the economy and protect their socially disadvantaged populations to the same extent as the industrialised countries. However, many countries have made considerable efforts to mitigate the effects. Emerging market and developing economies face additional challenges with unprecedented reversals in capital flows as global risk appetite wanes, and currency pressures, while coping with weaker health systems, and more limited fiscal space to provide support. Moreover, several economies entered this crisis in a vulnerable state with sluggish growth and high debt levels. ${ }^{3}$

Given the world reality, we see all the negative signs that characterize the economic crisis. The sharp decline in production, the total rise in unemployment, and the panicked fear of the virus have led to public outrage and depression. That is why the EU countries reached an agreement "to support the economy affected by the coronavirus epidemic" on April 9, 2020 and planned anti-crisis measures. ${ }^{4}$ One of the central points in the agreement is the support of business, as the basis of the country s economy.

As for Georgia, despite some attempts and due to subjective and objective reasons, the system of business support from the state is unfortunately not flexible and effective. In terms of private business, we are a relatively young country, so we do not lose hope that the economy of our country will also rely on the private sector for the next 20 years and therefore more reasonable and effective reforms will be implemented.

\footnotetext{
${ }^{1}$ https://blogs.worldbank.org/developmenttalk/common-measures-help-small-businesses-during-covid

${ }^{2} \mathrm{https} / / /$ www.borenius.ru/en/2020/05/covid-19-epidemic-overview-of-state-measures-to-support-business/

${ }^{3}$ https://journals.openedition.org/poldev/144

${ }^{4}$ https://www.consilium.europa.eu/en/press/press-releases/2020/04/09/report-on-the-comprehensive-economicpolicy-response-to-the-covid-19-pandemic/\#
} 


\section{REFERENCES}

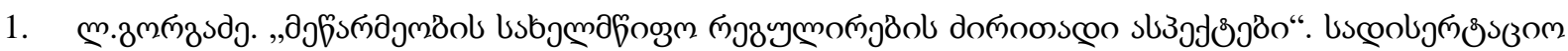
Бsəљмап. 2020.

2. Правовое регулирование и государственной поддержки малого предпринимательства в Германии. Гималетдинова К. А. Свинцицкая Е.В. 2019;

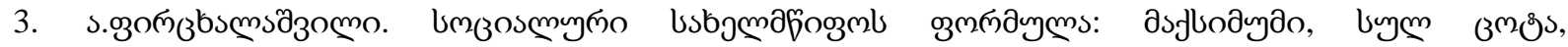
doбodydobsozzol. European.ge.2017.

4. Государственное регулирование рыночной экономики. Под ред. Кушлина В.И. 2-е изд., перераб. и доп. - М.: РАГС, 2005;

5. Рубе В.А. Малый бизнес: история, теория, практика. - М.: ТЕИС, 2000.p. 72

6. http://www.nplg.gov.ge/gwdict/index.php?a=term\&d=5\&t=16350

7. http://www.economy.ge/uploads/ecopolitic.

8. https://blogs.worldbank.org/developmenttalk/common-measures-help-small-businesses-during-covid

9. https://blogs.worldbank.org/developmenttalk/common-measures-help-small-businesses-during-covid

10. https://www.borenius.ru/en/2020/05/covid-19-epidemic-overview-of-state-measures-to-support-business/

11. https://www.consilium.europa.eu/en/press/press-releases/2020/04/09/report-on-the-comprehensiveeconomic-policy-response-to-the-covid-19-pandemic/\#

12. https://www.consilium.europa.eu/en/press/press-releases/2020/04/09/report-on-the-comprehensiveeconomic-policy-response-to-the-covid-19-pandemic/\# 